\title{
Overview of Esophagogastric Ulcer in Slaughter House-Welfare and Biosecurity Measures at Pig Commercial Farm
}

\author{
Jovan BOJKOVSKI ${ }^{1}$, Ana VASIĆ ${ }^{1}$, Nemanja ZDRAVKOVIĆ ${ }^{1}$, Teodora VASILJEVIĆ ${ }^{2}$, Dragan ROGOŽARSKI ${ }^{3}$ \\ ${ }^{1}$ Faculty of Veterinary Medicine, University of Belgrade, Belgrade, Serbia \\ ${ }^{2}$ Patent Co, Mišićevo, Serbia \\ ${ }^{3}$ Specialistic Veterinary Insitute Požarevac, Požarevac, Serbia \\ *Corresponding author: bojkovski@vet.bg.ac.rs \\ Bulletin UASVM Veterinary Medicine 73(1) / 2016, \\ Print ISSN 1843-5270; Electronic ISSN 1843-5378 \\ DOI:10.15835/buasvmcn-vm: 11826
}

\begin{abstract}
In this paper we present the results concerning the frequency of esophagogastric ulcer in pigs during several years of research. In slaughterhouse „A“ the average age of pigs ranged from 6 to 7 months and they weight from 100 to $110 \mathrm{~kg}$. A total of 103 animals were examined (53 castrated males, 50 gilts mixbreed of Landrace, Yorkshire, Pietrain and Durroc). All pigs originated from one commercial farm with slaughterhouse within. In slaughterhouse „B" the average age of pigs ranged from 7 to 9 months and they weight from 100 to $120 \mathrm{~kg}$. A total of 107 animals were examined ( 72 castrated males, 35 gilts mixbreed of Landrace, Yorkshire, Pietrain and Durroc). Pigs originated from different commercial farms and were held in different production management. In slaughterhouse „A“ we established following results: enlargement of esophageal surface in 37 samples, erosions of esophageal part in 29 samples, ulcerations in 4 samples. . In slaughterhouse „B“ we established following results: enlargement of esophageal surface in 49 samples, erosions of esophageal part in 27 samples, ulcerations in 21 samples
\end{abstract}

Keywords: biosecurity, esophagogastric ulcer, pig, welfare

\section{INTRODUCTION}

Intensive pig production with current management conditions and with a number of technological procedures have influence on the occurrence of several breeding diseases i.e techopathies. One of the most present technopaties which is described as individual disease in literature is esophagogastric ulcer which is charaterised by erosions and ulcerations in esophagogastric and rarely glandular part of stomach. Esophagogastric ulcer is the disease of multifactorial origin whereas the major causes stand: genetic predisposition, nutrition, presence of some pathogenic microorganisms (Helicobacter pylori)(Bojkovski et.al.2008, 2010, 2014).
In commercial farms one can see pigs with chronical ulcers. Those animals are anemic because of occasional bleeding from ulcer(s), have smaller food intake and they loose weight. In these animals when exposed to additional stress in slaughterhouse depot, manipulation, insufficient dizziness before slaughter, the occurence of pale, soft and exudative (PSE) meat can be seen due to fast postmortal glycolysis. The PSE meat is too dry and more lose weight because of water release during thermal processes. It has unwanted sensory characteristics and poor maintenance so it cannot be sold as fresh meat but it is only used for processing (Bojkovski et.al 2013). 
In this paper we present the results concerning the frequency of esophagogastric ulcer in pigs during several years of research.

\section{MATERIALS AND METHODS}

The examination of stomach was done in two slaughterhouses of industrial type. Slaughterhouse "A" is situated in Belgrade area as a part of commercial farm. Slaughterhouse "A“ processes the meat of fattening pigs from own farm. In this case there is not transport of animals and period of stay in slaughterhouse depot. In slaughterhouse " $\mathrm{A}$ " the average age of pigs ranged from 6 to 7 months and they weight from 100 to $110 \mathrm{~kg}$. A total of 103 animals were examined (53 castrated males, 50 gilts mixbreed of Landrace, Yorkshire, Pietrain and Durroc). Slaughterhouse „B" processes meat from fattening pigs of different commercial farms and individual producers. In slaughterhouse „ $B$ “ the average age of pigs ranged from 7 to 9 months and they weight from 100 to $120 \mathrm{~kg}$. Total of 107 animals were examined $(72$ castrated males, 35 gilts mixbreed of Landrace, Yorkshire, Pietrain and Durroc).

In slaughter line we opened stomach, empty it and washed in order to see the inner surface. Photo was made from every sample. The samples for histological analysis were taken.

\section{RESULTS AND DISCUSSION}

The shape of stomach is baggy and placed transversal in abdomen. Two parts can be differentiated: left or cardiac and right or pyloric. There are two borders (dorsal and ventral) and two surfaces (cranial and caudal) and middle part - corpus ventriculi. In stomach there are two openings: one connecting stomach with esophagus
- ostium cardiacum, and one connecting it with small intestine- ostium pyloricum. Dorsal border is concave and signed as- curvatura ventriculi minor, laying between esophagus and duodenum. Ventral border is convex and signed as- curvatura ventriculi major. In order to see the inner surface for the examination the cut was made over curvatura ventriculi major. In stomach there are cutaneous and glandular mucosa and this type of stomach is called complex-ventriculus compositus. Part of stomach that has cutaneous mucosa and is situated in the part near to esopagus is calledpars oesophagica, or proventricularis. Other part with glandular mucosa is called true stomach - pars glandularis. The borderline is crease and there is a different coloration between two parts (Lončarević et al.,1997).

From Tab. 1 and 2 there is an obvious difference in occurrence of changes where in slaughterhouse "A" there were 4 ulcers $(4,12 \%)$ which change relief of esophageal region compared with 21 ulcers $(22,47 \%)$ found in slaughterhouse „B“ samples. Mucosal defects were round and oval, clearly differentiated from unchanged part of mucosa with slightly rounded borders over the ulcer (photo 1).

Of total of 4 positive samples in slaughterhouse „A“ 3 originated from male castrated animals and one sample was from a gilt. In slaughterhouse „B“ 11 positive samples were from male castrated animals and 10 from sows and gilts.

In major number of samples the changes were hyperkeratosis. The surface was firm, diffuse lined in the whole surface of cutaneous mucosa resembling the oak tree bark with different coloration from yellow to green (photo 2). These changes were found in $37(38,11 \%)$ samples from

Tab. 1. The examination of stomach in slaughterhose „A“

\begin{tabular}{lcc}
\hline \multicolumn{1}{c}{ Findings } & $\begin{array}{c}\text { No of positive } \\
\text { animals }\end{array}$ & $\begin{array}{c}\text { No of examined } \\
\text { animals }\end{array}$ \\
\hline $\begin{array}{c}\text { Enlargement of esophagogastric surface } \\
\text { Hyperkeratosis, unstractural yellow surface }\end{array}$ & 37 & 103 \\
\hline $\begin{array}{c}\text { Erosions of esophagogastric part- } \\
\text { Damage of surface which does not } \\
\text { include muscularis mucose }\end{array}$ & 29 & 103 \\
\hline $\begin{array}{l}\text { Ulcerations of esophagogastric part-Damage of } \\
\text { surface which does include muscularis mucose }\end{array}$ & 4 & 103 \\
\hline
\end{tabular}


slaughterhouse „A“ compared to $49(52,43 \%)$ from slaughterhouse „B“.

With hyperkeratosis we found erosions of different shape and size (Photo 3). Most commonly they were starting from periphery i.e. from the border with cardia and erosions were surrounded by hyperemic and edematous mucosa.

The closed management process is performed in commercial farm "A“ and animals which come to slaughterhouse originate from the same category. The number of animals with esophagogastric ulcer found is not significant compared to the total number of samples, so it can be said that on this farm esophagogastric ulcer is not a significant health problem. In higher percentage we established hyperkeratosis on cutaneous mucosa most probably as a consequence of nutrition with finely divided concentrated feedstuff and lacking natural wear of cutaneous mucosal epithelium.

Disturbances in keratosis and the emergence of erosion could be the result of prolonged acidosis related to the chemical processes of digestion under the influence of gastric juice.

Samples in which are found ulcers came from the animals, which according to the data obtained from the farm, were treated for enteritis of different etiology. In addition to ulceration, the stomachs of these animals are with thickened walls, filled with acid, yellow, sparkling content. All this indicates that some of the factors that are attributed to the occurrence of disease and lasting different periods of time that can lead to some of the changes described in cutaneous mucosa.

To have a profitable production on commercial pig farms it is necessary to estimate biosafety. Rating biosafety on the basis of indicators (the isolation as a measure of biosecurity on farms, quarantine, evaluation of the health status of the herd, the way of use of equipment by personnel, animal movement control and traffic, visitors regime, control of food and equipment for feeding, manure, removing the corpses of dead animals,

Tab. 2. The examination of stomach in slaughterhouse „B“

\begin{tabular}{ccc}
\hline Findings & $\begin{array}{c}\text { No of positive } \\
\text { animals }\end{array}$ & $\begin{array}{c}\text { No of examined } \\
\text { animals }\end{array}$ \\
\hline $\begin{array}{c}\text { Enlargement of esophagogastric surface } \\
\text { Hyperkeratosis, unstractural yellow surface }\end{array}$ & 49 & 107 \\
\hline $\begin{array}{c}\text { Erosions of esophagogastric part- } \\
\text { Damage of surface which does not } \\
\text { include muscularis mucose }\end{array}$ & 27 & 107 \\
\hline $\begin{array}{c}\text { Ulcerations of esophagogastric } \\
\text { part-Damage of surface which does } \\
\text { include muscularis mucosae }\end{array}$ & 21 & 107 \\
\hline
\end{tabular}

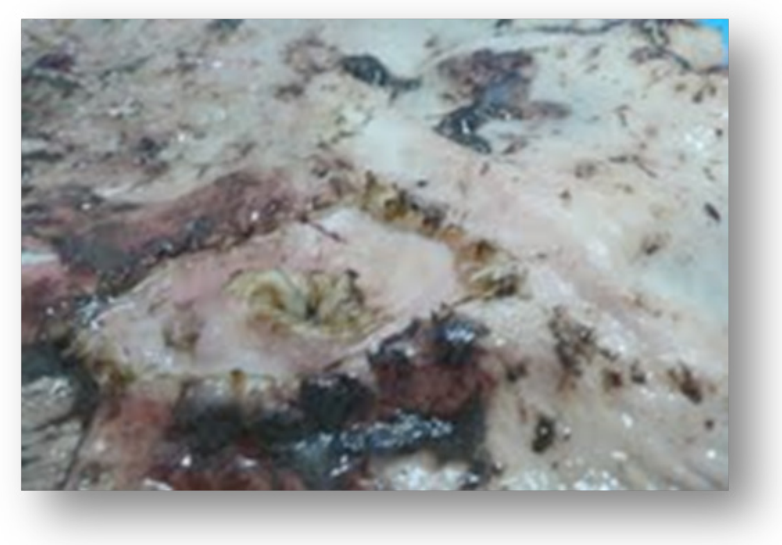

Photo 1. Esophagogastric ulcer clearly differentiated from healthy mucosa (original photo)

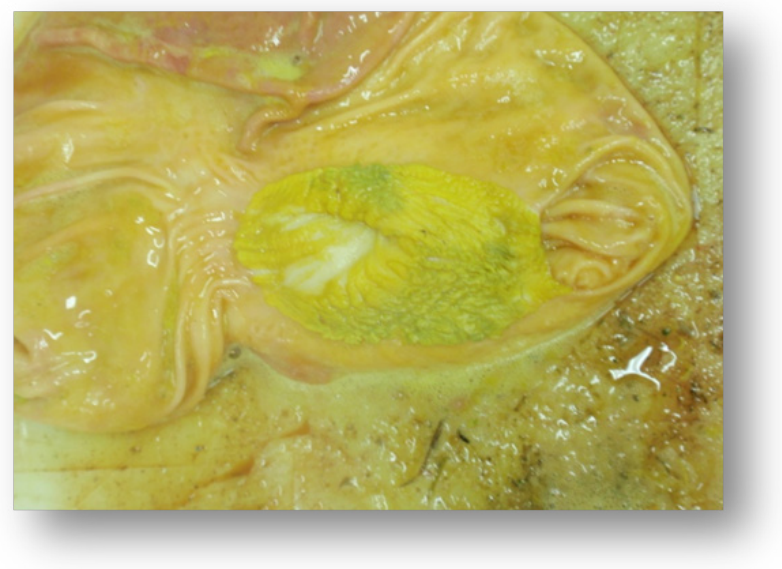

Photo 2. Hyperkeratosis of cutaneous mucosa (original photo) 


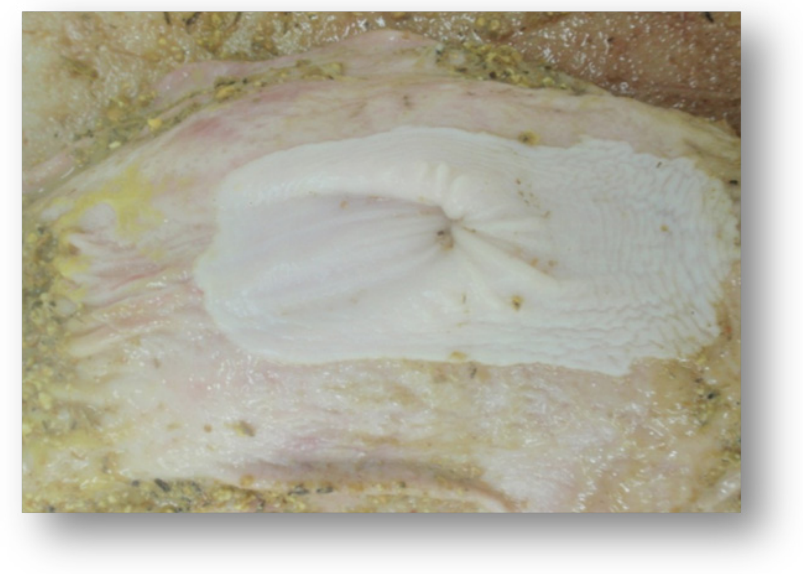

Photo 3. Erosions of different shape and size (original photo)

relation to other farm animals, control of birds and rodents) should be routine in the assessment of biosecurity on farms, which indicates the way to act and a possible additional improvements of their (Stankovic et al., 2008).

Ratings of biosecurity on commercial farms indicate the current state of biosecurity of the farm, but one must always bear in mind the interaction and the totality of biosafety action parameters (Stankovic et.al.2010). The owners of the farmbreeders have the greatest responsibility to protect its own herd in terms of introduction of the disease and movement control, proper production process and placement of animal group and sanitation. Farm workers and farm visitors must be aware of their role in the preservation of safe health status of farms (Stankovic et.al., 2010).

Today, more and more attention is paid to welfare on commercial pig farms. Recommendations of welfare standards are given for all categories of pigs (Anon, 2008). Maintaining good animal health is the most important condition for maintaining the welfare of pigs. Pigs should stay in enriched living space to be able to investigate environment, chew and play. Straw is a very good material because it meets the physical needs of pigs and allow to express certain behaviors. Nutrition of pigs should include fibrous materials that animals can consume, allowing them to chew and play, and when used as litter to give them a sense of physical and thermal comfort (Deen, 2010). Technopaties like biting tails, ears and hips are consequences of some kind of stress. They can be caused by a large number or combination of factors, including overcrowding, lack of nutrients,

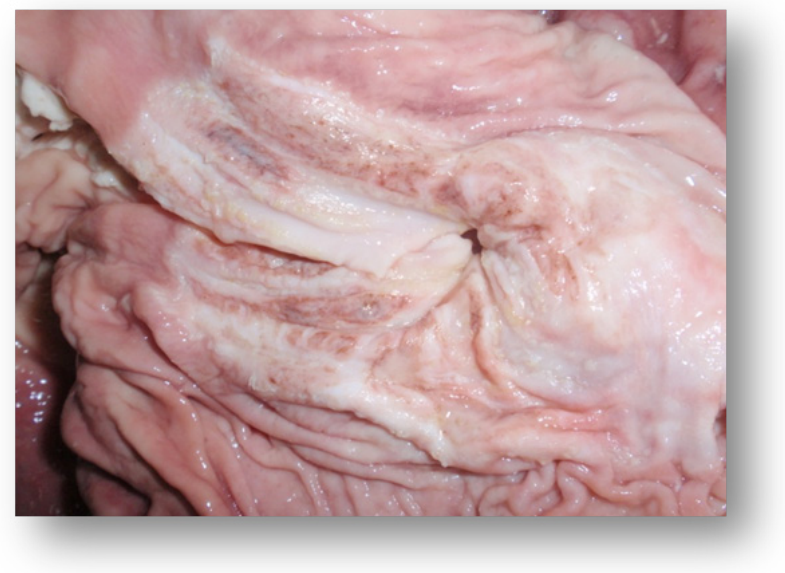

Photo 4. Mucosa of esophageal region without changes (original photo)

insufficient number of feeders, improper ambient temperatures, unsufficient ventilation, draft, a large amount of dust, high levels of harmful gases (Petrovic, 2007). The diet should provide to sows and gilts necessary nutrients, so that they are in good physical condition during farrowing. The problems that arise in the course of weaning depend on the age of weaning piglets. The young the piglets are in the period of refusal, the better the growing conditions and nutrition shoud be in order to avoid problems related to animal welfare (Deen, 2010).

\section{CONCLUSION}

In slaughterhouse "A“ from 103 examined animals we established: thickening of esophageal surface (hyperkeratosis, unstructional yellow surface) in 37 animals, erosions of esophageal part (surface damage which does not include muscularis mucose) in 29 animals and ulceration of esophageal part (damage which does include muscularis mucose) in 4 animals.

In slaughterhouse „B“ from 107 examined animals we established: thickening of esophageal surface (hyperkeratosis, unstructional yellow surface) in 49 animals, erosions of esophageal part (surface damage which does not include muscularis mucose) in 27 animals and ulceration of esophageal part (damage which does include muscularis mucose) in 21 animals.

Health care of pigs in commercial farms has to be based on prophylactic measures and less on therapy. In that way the concept of having both, profitable production and control of factors 
which can influence health status of animals can be fulfilled. Therefore, the rating of biosecurity on farm and estimation of animal welfare are key elements in resolving the occurrence of technopaties in pig farms.

\section{Conflict of interest}

The authors declare that they have no conflict of interest.

Statement of ethical compliance Experiment was done in compliance with Serbian Law on Animal Welfare (Official Gazette of the Republic of Serbia No 41/09)

Aknowledgements. This research has been support by Ministry of Science, Education and Technological development of the Republic of Serbia, project TR31071

\section{REFERENCES}

1. Anon A (2008). Introduction to the recommendations for animal welfare. Article 7.1.1.In : Terrestrial Animal Health Code 2008. World Organization for Animal Health (OIE), Paris, France, 235-236.

2. Bojkovski J, Janjušević J, Rogožarski D, Savić B, Stojanović D, Pavlović I , Đedović S (2013). Contribution to knowledge of esophgogastirc ulcer by swine in Serbia ( case report). Lucrări Stiintifice Medicină Veterinară Timisoara, XLVII(4):17-23.

3. BojkovskiJ, Vasić A, Zdravković N, Milanov D, Rogožarski D (2014). Esophagogastric ulcer in pigs on commercial farms. Proceeding of the International Symposium on Animal Science, September 2014, Belgrade -Zemun, 354360.

4. Bojkovski J, Relić R, Hristov S, Stanković B, Savić B, Petrujkić T (2010). Contribution to knowledge of health, reproduction,biosecurity and ecological problems in intensive pig production. Bulletin UASVM,Veterinary Medicine 67(2): 37-39.

5. Bojkovski J, Radojičić B, Petrujkić T, Borozan S (2008). A contribution to insight of the most important etiological factors with influence of farm animal health in Serbia. Proceedings of the International Symposium on new research in biotehnology, Bucharest, Romania, Biotehnology , Special volume(F):101-114.

6. Deen J (2010). Pigs: Behaviour and welfare assessment. Encyclopedia of Animal Behaviour, 731-7.

7. Lončarević A, Maričić Z, Tosevski J, Pavlović I (1997). Osnove sistematskog zdravstvenog nadzora i programiranje zdravstvene zaštite svinja u intenzivnom odgoju. U monografiji: A Lončarević: Zdravstvena zaštita svinja u intenzivnom odgoju, Izd.: Naučni institut za veterinarstvo Srbije, Beograd, 517-523

8. Petrović Milica, Stanković B, Hristov S, JoksimovićTodorović Mirjana, Davidović Vesna, Božić A (2007. Minimalni standardi o uslovima gajenja i dobrobiti svinja. U monografiji: Dobrobit životinja i biosigurnost na farmama, Poljoprivredni fakultet, Zemun, 173-185.

9. Stanković B, Hristov S, Petrujkić T, Todorović-Joksimović Mirjana, Davidović Vesna, Bojkovski J (2008). Biosigurnost na farmama svinja u svakodnevnoj praksi. Biotechnology in animal husbandry 24:601-608.

10. Stanković B, Hristov S, Bojkovski J, Maksimović N (2010). Zdravstveni status i biosigurnosni planovi na farmama svinja. Biotechnology in Animal Husbandry 26(1-2):2935. 